\title{
Combined Effects of Dewatering, Composting and Pelleting to Valorize and Delocalize Livestock Manure, Improving Agricultural Sustainability
}

\author{
Domenico Ronga ${ }^{1,2,3, *(\mathbb{C})}$, Paolo Mantovi ${ }^{3}$, Maria Teresa Pacchioli ${ }^{1}{ }^{(0)}$, Andrea Pulvirenti ${ }^{4}{ }^{(}$,

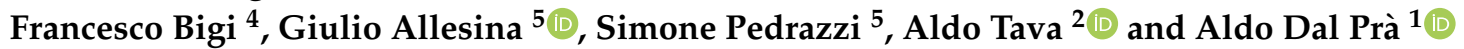 \\ 1 Centro Ricerche Produzioni Animali-CRPA S.p.A, Viale Timavo, n. 43/2, 42121 Reggio Emilia, Italy; \\ m.t.pacchioli@crpa.it (M.T.P.); a.dalpra@crpa.it (A.D.P.) \\ 2 Council for Agricultural Research and Economics-Research Centre for Animal Production and Aquaculture, \\ Viale Piacenza, 29, 26900 Lodi, Italy; aldo.tava@crea.gov.it \\ 3 Fondazione CRPA Studi Ricerche, Viale Timavo, n. 43/2, 42121 Reggio Emilia, Italy; p.mantovi@crpa.it \\ 4 Department of Life Sciences, University of Modena and Reggio Emilia, Via Amendola, n. 2, \\ 42122 Reggio Emilia, Italy; andrea.pulvirenti@unimore.it (A.P.); francesco.bigi@unimore.it (F.B.) \\ 5 Department of Engineering 'Enzo Ferrari', University of Modena and Reggio Emilia, Via Vivarelli, n. 10, \\ 41125 Modena, Italy; giulio.allesina@unimore.it (G.A.); simone.pedrazzi@unimore.it (S.P.) \\ * Correspondence: domenico.ronga@unimore.it; Tel.: +39-339-6805848
}

Received: 31 March 2020; Accepted: 6 May 2020; Published: 8 May 2020

\begin{abstract}
An agronomic strategy to mitigate climate change impact can be the build-up of soil organic carbon. Among agronomic management approaches, the administration of organic fertilizers like livestock manure represents an effective strategy to increase soil organic carbon. However, livestock manure usually contains a high amount of water, reducing its sustainable delocalization and impacting on greenhouse gas emissions and nutrient leaching. Furthermore, the possible presence of weed seeds and harmful microorganisms could reduce the agronomic value of the manure. To overcome these issues, the combined effects of dewatering, composting and pelleting were investigated on livestock manure to produce sustainable organic fertilizers. Our results showed that composting and pelleting can represent a feasible and sustainable solution to reduce the potential risks related to the presence of weed seeds and harmful bacteria, concentrating nutrients and allowing a sustainable valorization and delocalization of the livestock manure. In addition, the processed manures were assessed as fertilizers in the growing medium (GM), displaying an increase in water retention and nutrient availability and a decrease of GM temperature and weed seed emergences. However, further study is needed to validate, both in open field and greenhouse productions, the effects of the proposed fertilizers in real cropping systems.
\end{abstract}

Keywords: cattle; dairy farming; growing media; nutrient; organic carbon; sustainability; water

\section{Introduction}

The increase of the soil organic carbon (SOC) content represents one of the most common agronomic practices to mitigate climate change impacts [1,2]. Farmers can adopt different agronomic strategies to increase the SOC content and, among them, the administration of livestock manure is one of the most used [3], especially in dairy areas.

Livestock manure contains a relatively greater proportion of organic carbon and mineral nutrients; hence, livestock manure might be used to partially replace inorganic fertilizers in crop production [4-7].

Nowadays the demand for an increase in food production and the necessity to reduce the production costs is leading to a worldwide increase in the utilization of cheaper fertilizers such as 
organic ones. However, the nutrient availability of the livestock manure sometimes is not properly exploited. Current management and application of the raw manure can contribute to reduced soil and water qualities due to the leaching of nutrients and phytotoxic elements [8]. Moreover, livestock manure can only be used in soil close to the production site due to its greater water content, reducing its possible delocalization [9]. Lastly, other problems related to the use of the livestock manure can be the presence of weed seeds and harmful microorganisms $[10,11]$.

Currently, composting represents one of the most common methods used to valorize different organic by-products allowing their utilization as a soil amendment [12-15].

From this point of view, composting is a fundamental process both in terms of the stability and availability of nutrients contained in the organic matrices as well as for a correct recycling of the by-products, especially for sustainable management of soil fertility [16].

The use of composted livestock manure is favored over untreated manure due to its lower volume and smaller particle size, allowing an easier handling and facilitating a higher uniform application [9]. Considering all these aspects, manure valorization through the production of organic fertilizers is a promising solution to increase the sustainable management of the manure, especially in agricultural areas with a high livestock concentration, as well as in areas affected by groundwater nitrate pollution [17].

Dewatering (solid-liquid separation) and composting are two processes that can reduce the water content and the load of harmful microorganisms of the livestock manure. However, composting is commonly conducted with an average temperature of $\sim 70{ }^{\circ} \mathrm{C}$, that does not allow a drastic reduction of the microbial populations $[18,19]$. In addition, dewatering and composting are not able to reduce the water content of the organic matrices under $30 \%$ and the possible presence of seed weeds might reduce the agronomic valorization of the products obtained. In this respect, Pulvirenti et al. [20] reported that pelleting might be an available solution to drastically reduce the water content to $\sim 7 \%$ and inactivating harmful microorganisms contained in the solid digestate.

Livestock manure can be used as an eco-friendly source considering that the majority of nutrients contained in the livestock manure remain after the dewatering, composting and pelleting processes [20-23].

To the authors' knowledge, there are few reports on these aspects, and taking into account all the aspects mentioned above, the aim of the present work was to provide feasible technologies to produce organic fertilizers, valorizing livestock manure.

The combined effect of dewatering, composting and pelleting was assessed to reduce the water content, the harmful microorganisms and the seed weeds in the organic fertilizers produced from livestock manure, allowing safe use and sustainable delocalization of the organic fertilizers suitable also for their use under organic farming system in accordance with the Fertilizing Products Regulations (EU) 2019/1009 and (EU) 2019/1010.

\section{Materials and Methods}

The present study was performed using livestock (cattle) manures collected from a farm that produces the PDO (Protected Denomination of Origin) cheese Parmigiano Reggiano, located in Felina, Reggio Emilia, Italy $\left(44^{\circ} 27^{\prime} 01.2^{\prime \prime} \mathrm{N} 10^{\circ} 28^{\prime} 07.1^{\prime \prime}\right.$ E, altitude $664 \mathrm{~m}$ a.s.1.).

Latteria Sociale del Fornacione provided two types of manures for this study: farmyard manure and solid fraction of the dewatered slurry. Fresh dairy slurry was separated into liquid and solid phases using a screw press solid-liquid separator. Subsequently, both farmyard manure and dewatered slurry were composted through a static pile of $2 \mathrm{~m}^{3}$ (on the farm) for 113 days, and turned weekly.

Composting temperature was recorded through a PT100 thermal sensor (Gandolfi, Parma, Italy), situated in the center of the pile. Fifty-five days of thermophilic phase were followed by a further 2-month curing period. Each of the raw materials and the compost obtained were sampled at different points of the pile and two bulk samples were analyzed for the following parameters: $\mathrm{pH}$, electrical conductivity (EC), total solid (TS), total nitrogen $(\mathrm{N})$, ammoniacal $\mathrm{N}\left(\mathrm{N}^{-\mathrm{NH}_{4}}{ }^{+}\right)$, total organic 
carbon (TOC), ratio between TOC and $\mathrm{N}(\mathrm{C} / \mathrm{N})$, total phosphorous $(\mathrm{P})$, potassium $(\mathrm{K})$, total extractable carbon (TEC), humic and fulvic acids (HA + FA), non-humified fraction(NH), degree of humification $(\mathrm{DH})$, humification rate $(\mathrm{HR})$, humification index $(\mathrm{HI})$, according to the respective procedures indicated in Baffi et al. [24] and Ronga et al. [25]. Moreover, the dewatered and composted slurry was pelleted as described by Pulvirenti et al. [20] and analyzed for the main chemical parameters (TS, N, TOC, C/N, $\mathrm{P}$ and $\mathrm{K}$ ) as described above. Pelleting was only applied on dewatered and composted slurry because it was the only material that showed the complete absence of stones, an important characteristic to avoid any damage during the pelleting phase.

All the fertilizers investigated (farmyard manure, dewatered slurry, compost and pellet) were also analyzed to determine the presence of aerobic mesophilic colony forming unit and Enterobacteriaceae as reported by Setti et al. [12] and Clostridia spp. as described by Ronga et al. [26].

In addition, farmyard manure, dewater slurry (fresh and composted) and pellets were investigated in a preliminary study to assess their use as fertilizer in a growing medium like peat. A potting experiment was performed in a growth chamber with programmed temperature ranging from 23 to $19^{\circ} \mathrm{C}$ (day/night), relative humidity ranging from $50 \%$ to $60 \%$, and a photoperiod composed of $16 \mathrm{~h}$ of light and $8 \mathrm{~h}$ of dark. Plastic pots (diameter $10 \mathrm{~cm}$ and height $8 \mathrm{~cm}, 0.4 \mathrm{~L}$ ) were filled with commercial peat (Fondolinfa ${ }^{\circledR}$ Universale, Linfa Spa, RE, Italy). Each pot was placed in a pot saucer and arranged in a completely randomized design with five replicates; pots were manually irrigated every day up to the GM water capacity. Briefly, the experiment was carried out using $0.1 \mathrm{~g} \mathrm{of} \mathrm{N} \mathrm{pot}^{-1}$ for each treatment (farmyard manure, dewater slurry (fresh and composted) and pellets) and monitored for 30 days for the following parameters: GM humidity, temperature and EC (using a sensor Teros 11/12, Meter Group, Washington, USA), weed emergence and $\mathrm{N}$ mineralized and lost (calculated as the difference between total $\mathrm{N}$ at the beginning of the experiment and total $\mathrm{N}$ at the end; $\mathrm{N}$ was measured as described before).

The experimental data were analyzed using GenStat 17th software (VSN International, Hemel Hempstead, UK) for analysis of variance (ANOVA). Means were compared using Duncan's test at $p<0.05$.

\section{Results and Discussion}

Butler et al. [14] reported that the main beneficial agronomic effects of adopting composted manure are the stability and maturity of the product obtained. In fact, in the case of using untreated organic residues as soil improver, an imbalance in nutrient availability and phytotoxicity effects can be observed on plant growth.

As expected, the principal effect of dewatered slurry was a remarkable increase in important parameters such as total solids, total organic $\mathrm{C}$ and $\mathrm{C} / \mathrm{N}$, and decreasing EC (Table 1) compared to the raw slurry.

Regarding composting effect, both for farmyard manure and dewatered slurry, a significant increase of the following parameters was observed: $\mathrm{pH}, \mathrm{TS}, \mathrm{N}, \mathrm{P}, \mathrm{K}$ and DH. Meanwhile, a decrease of the $\mathrm{C} / \mathrm{N}$ was recorded, due to the partial organic matter degradation and an increase of $\mathrm{N}$. In addition, during composting, in both the piles (farmyard manure and dewatered slurry) the thermophilic phase recorded temperature values that exceeded $60^{\circ} \mathrm{C}$ for at least 14 days (data not shown), as requested to achieve good sanitation. Our data agreed with several published works performed on different composted organic matrices [16,26-29].

Pelleting was carried out only on dewatered and composted slurry which, compared to composted farmyard manure, displayed the complete absence of stones. This characteristic is mandatory because the presence of stones, even in small size $(<2 \mathrm{~mm})$, could cause serious damage to the machine during the pelleting phase. When compared to dewatering and composting, pelleting showed a drastic increase of the concentration of specific nutrients (TOC, N and P and K). This effect can be mainly ascribed to the drastic reduction of the water content of the assessed material from $\sim 29 \%$ to $\sim 8 \%$, as already reported by Pulvirenti et al. [20]. In addition to the expected beneficial effect on the nutrient concentration, the reduced water content can allow a cheaper transportation and distribution of the 
organic fertilizers, valorizing their delocalization and sustainable use. In fact, Hara [30] suggested that composted livestock manure is difficult and costly to transport due its high moisture content and a high volume per unit of weight, as well as a large storage space is required. The same author reported that the production costs are related to the volume of the fertilizer produced, indicating an average cost of $\sim 3.00$ euro per $20 \mathrm{~kg}$ bag. Finally, the cost of fertilizer is largely determined by the transport and distribution costs. Ncube et al. [31] indicated that transport costs often accounting for $\sim 50 \%$ of the delivered price to farmers.

Table 1. Chemical characteristics of the raw and processed livestock manures.

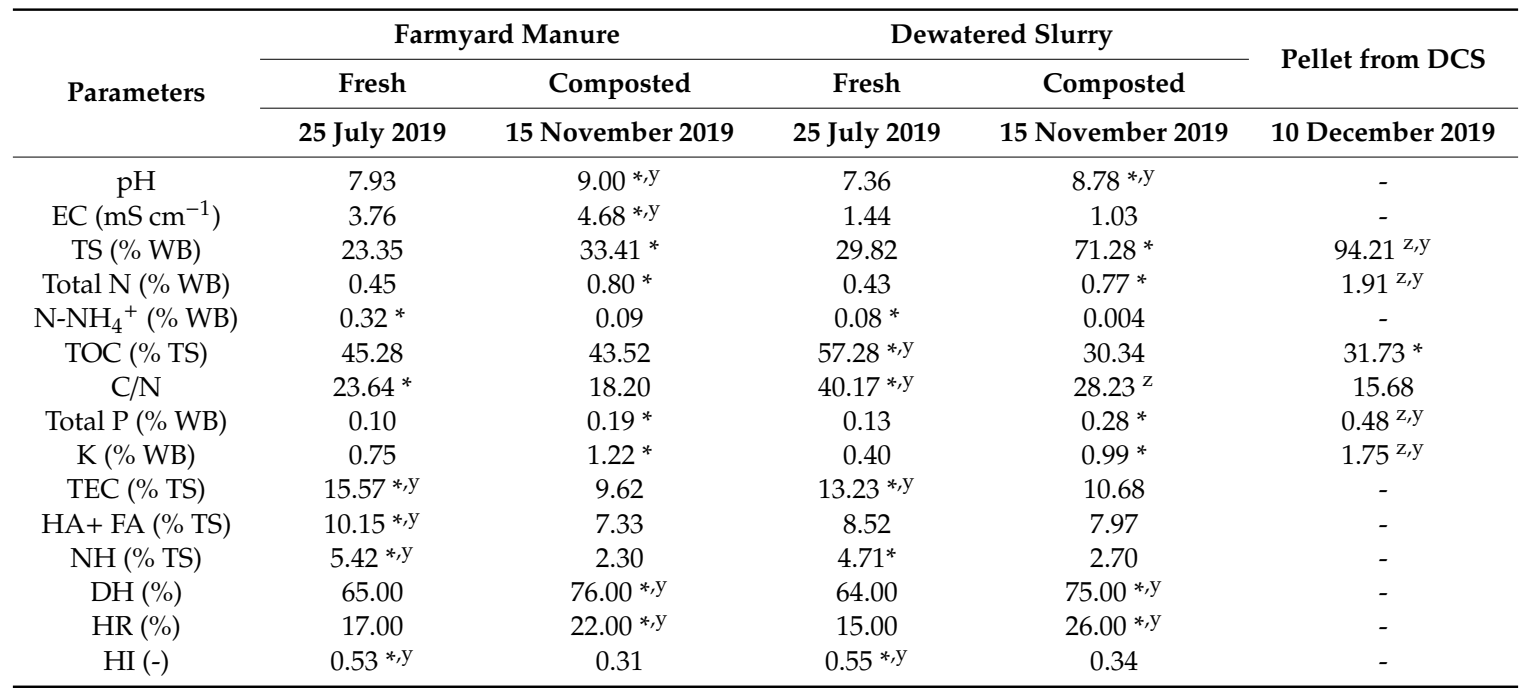

$\mathrm{EC}=$ electrical conductivity, $\mathrm{TS}=$ total solids, $\mathrm{WB}=$ wet basis, $\mathrm{N}=$ nitrogen, $\mathrm{N}_{-} \mathrm{NH}_{4}{ }^{+}=$ammoniacal $\mathrm{N}, \mathrm{P}=$ total phosphorus, $\mathrm{K}=$ potassium, TEC = total extractable carbon, HA + FA = humic and fulvic acids, NH = non-humified fraction, $\mathrm{DH}=$ degree of humification, $\mathrm{HR}=$ humification rate, $\mathrm{HI}=$ humification index, $\mathrm{DCS}=\mathrm{dew}$ atered and composted slurry. ${ }^{*}=$ indicates a significant difference between fresh and composted organic fertilizer. For DCS, ${ }^{\mathrm{z}}$ is used for significant difference compared to composted and dewatered slurry. ${ }^{\mathrm{y}}=$ indicates a significant difference among the values of the same row.

Regarding the microbiological analysis (Table 2), the dewatered and composted slurry showed the highest load of aerobic mesophilic bacteria, while the lowest values of Enterobacteriaceae and Clostridia spp. were detected in the same pelleted material (dewatered and composted slurry). These results are in accordance with the data reported by Setti et al. [12] and Pulvirenti et al. [20]. Pelleting-derived material displayed better microbial characteristics than composting-derived one because only vegetative microbial cells are sensitive to temperatures lower than $65^{\circ} \mathrm{C}$ (recorded during composting), while the reduction of bacterial spores can be obtained by reaching higher temperatures [32]. In fact, high pressure and temperature $\left(\sim 90^{\circ} \mathrm{C}\right)$ reached during the pelleting phase were probably the main causes of the drastic reduction of the microorganisms investigated [20]. However, the fertilizers obtained could allow the re-growth of microorganisms due to a non-hygienic condition, especially if not properly stored [33].

The organic fertilizers studied in the present work were also investigated in a short-term potting experiment in order to assess their main agronomic effects on the growing medium like peat. All the tested fertilizers increased the water retention of peat, reducing its temperature and increasing EC (Table 3).

Using composted farmyard manure, dewatered and composted slurry and the latter pelleted, no emergence of any weed was recorded, while an average value of one weed per pot was observed for the pots fertilized with the farmyard manure and dewatered slurry. 
Table 2. Main microbiological parameters assessed on raw and processed livestock manures.

\begin{tabular}{|c|c|c|c|c|c|c|}
\hline \multirow{2}{*}{$\begin{array}{c}\text { Treatments } \\
\text { Farmyard manure }\end{array}$} & \multicolumn{2}{|c|}{$\begin{array}{l}\text { Aerobic Mesophilic } \\
\text { Bacteria (CFU g-1) }\end{array}$} & \multicolumn{2}{|c|}{ 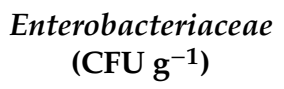 } & \multicolumn{2}{|c|}{$\begin{array}{l}\text { Clostridia spp. } \\
\quad\left(\mathrm{CFU} \mathrm{\textrm {g } ^ { - 1 } )}\right.\end{array}$} \\
\hline & $3.20 \times 10^{6}$ & $\mathbf{e}$ & $1.05 \times 10^{6}$ & $b$ & $8.56 \times 10^{4}$ & $b$ \\
\hline Composted farmyard manure & $2.06 \times 10^{8}$ & $\mathrm{~b}$ & $7.81 \times 10^{4}$ & $\mathrm{~cd}$ & $3.55 \times 10^{4}$ & $\mathrm{c}$ \\
\hline Dewatered slurry & $9.07 \times 10^{7}$ & c & $1.19 \times 10^{5}$ & c & $1.23 \times 10^{4}$ & $\mathrm{~d}$ \\
\hline Dewatered and composted slurry & $2.79 \times 10^{8}$ & a & $2.80 \times 10^{6}$ & a & $1.66 \times 10^{6}$ & a \\
\hline Pelleted-DCS & $4.84 \times 10^{6}$ & de & $8.71 \times 10^{3}$ & $\mathrm{~d}$ & $1.25 \times 10^{4}$ & $\mathrm{~d}$ \\
\hline
\end{tabular}

DCS = dewatered and composted slurry; CFU = colony forming unit. Means followed by the same letter do not significantly differ at $p<0.05$.

Table 3. Parameters investigated in the potting experiment using raw and processed livestock manures as organic fertilizers.

\begin{tabular}{|c|c|c|c|c|c|c|c|c|c|c|}
\hline \multirow{2}{*}{$\begin{array}{c}\text { Treatment } \\
\text { Not fertilized }\end{array}$} & \multicolumn{2}{|c|}{$\begin{array}{l}\text { Volumetric Water } \\
\text { Content }\left(\mathrm{m}^{3} \mathrm{~m}^{-3}\right)\end{array}$} & \multicolumn{2}{|c|}{$\begin{array}{c}\text { GM Temperature } \\
\left({ }^{\circ} \mathrm{C}\right)\end{array}$} & \multicolumn{2}{|c|}{$\begin{array}{l}\text { GM Electrical } \\
\text { Conductivity } \\
\left(\mathrm{mS} \mathrm{cm}^{-1}\right)\end{array}$} & \multicolumn{2}{|c|}{$\begin{array}{l}\text { Weed Emergence } \\
\text { (no. } \text { pot }^{-1} \text { ) }\end{array}$} & \multicolumn{2}{|c|}{$\begin{array}{c}\text { Nitrogen Mineralizd } \\
\text { and Lost } \\
\left(\mathrm{g} \mathrm{kg}^{-1}\right)\end{array}$} \\
\hline & 0.11 & $\mathrm{~d}$ & 25.2 & a & 0.39 & c & 0 & $\mathrm{~b}$ & - & \\
\hline Farmyard manure & 0.14 & c & 25.0 & $\mathrm{~b}$ & 0.47 & $\mathrm{~b}$ & 1 & a & 0.004 & $\mathrm{~d}$ \\
\hline Composted farmyard manure & 0.12 & c & 25.1 & $a b$ & 0.41 & bc & 0 & $\mathrm{~b}$ & 0.009 & c \\
\hline Dewatered slurry & 0.16 & $\mathrm{~b}$ & 24.8 & c & 0.53 & $\mathrm{ab}$ & 1 & a & 0.027 & a \\
\hline Dewatered and composted slurry & 0.18 & $\mathrm{~b}$ & 24.7 & $\mathrm{~b}$ & 0.57 & $\mathrm{a}$ & 0 & $\mathrm{~b}$ & 0.016 & $\mathrm{~b}$ \\
\hline Pelleted-DCS & 0.20 & $\mathrm{a}$ & 24.4 & c & 0.56 & a & 0 & $\mathrm{~b}$ & 0.018 & $\mathrm{~b}$ \\
\hline
\end{tabular}

Finally, among the organic fertilizers tested in the pot experiment, dewatered slurry displayed the highest value of $\mathrm{N}$ mineralized and lost, followed by dewatered and composted slurry and the latter pelleted. Considering these results, the fertilizers showing a high $\mathrm{N}$ mineralized with a high capacity to increase soil water retention might be used in the production of crops that require greater availability of $\mathrm{N}$ and water such as tomato [34-37]. Moreover, farmyard manure and composted farmyard manure displayed lower values of $\mathrm{N}$ mineralized and lost, probably due to the lower values of the volumetric water content of the growing medium; however, further investigation is required to corroborate this hypothesis.

Mineralization is driven by microorganisms and affected by several factors such as temperature, soil moisture, soil properties, and manure characteristics [38]. Among nutrients, $\mathrm{N}$ mineralization is reported to increase with increasing soil temperature [39,40]. In addition, mineralization is high with the value of soil moisture close to the field capacity, and declining when soil is drying [39]. This information fits with the results recorded during the potting experiment. In fact, the highest values of $\mathrm{N}$ mineralized and lost were displayed for the treatments related to high values of water retention, while temperatures, even if statistically different, fluctuated in a short range between $24.4^{\circ} \mathrm{C}$ and $25.2^{\circ} \mathrm{C}$.

\section{Conclusions}

To the authors' knowledge, this is the first study to investigate the suitability of a combined effect of the proposed technologies to valorize and delocalize livestock manure. The pellets obtained in the present study showed a drastic reduction of water content and of harmful microorganisms. Furthermore, they were free of weed seeds. Pellets also displayed a high nutrient availability, improving water retention and reducing the temperature of the growing medium. Considering the importance of organic matter to mitigate climate change, the combined effect of the proposed technologies reduced the TOC, however, maintaining the most stable carbon, and allowing a higher delocalization of the livestock manure from the production sites. Therefore, despite the need for further investigations, the combined effects of dewatering, composting and pelleting might be proposed as a suitable solution to reduce water content, harmful microorganisms and weed seed, increasing nutrient concentration and the sustainable delocalization of the livestock manure. However, further research is needed to 
validate our preliminary results more in depth, especially on the economic sustainability and impacts of greenhouse gas emissions and as well as the agronomic effects, both in the open field and greenhouse crop production, of the proposed fertilizers at real farm scale.

Author Contributions: Conceptualization, M.T.P. and D.R.; methodology, A.D.P. and P.M.; software, D.R.; formal analysis, D.R. and P.M.; investigation, D.R., A.D.P., P.M., A.P., F.B., G.A., S.P., A.T.; resources, A.D.P. and P.M.; data curation, D.R.; writing—original draft preparation, D.R.; writing-review and editing, D.R., M.T.P., A.D.P., P.M., A.T., F.B., A.P.; funding acquisition, A.D.P. and P.M. All authors have read and agreed to the published version of the manuscript.

Funding: This research was funded by the Emilia-Romagna RDP 2014-2020 (Italy), “domanda di aiuto n. 5015780, Focus Area 5 E" and the work was carried out within the Operational Group CARBONIO DI MONTAGNA.

Acknowledgments: The authors acknowledge all the staff and students of CRPA and University of Modena and Reggio Emilia, who generously collaborated with the collection and analysis of the data. The authors thank Giuseppe Bonazzi for inspiring the project.

Conflicts of Interest: The authors declare no conflict of interest.

\section{References}

1. Cammarano, D.; Ceccarelli, S.; Grando, S.; Romagosa, I.; Benbelkacem, A.; Akar, T.; Al-Yassin, A.; Pecchioni, N.; Francia, E.; Ronga, D. The impact of climate change on barley yield in the Mediterranean basin. Eur. J. Agron. 2019, 106, 1-11. [CrossRef]

2. Cammarano, D.; Holland, J.; Ronga, D. Spatial and Temporal Variability of Spring Barley Yield and Quality Quantified by Crop Simulation Model. Agronomy 2020, 10, 393. [CrossRef]

3. Cai, A.; Xu, M.; Wang, B.; Zhang, W.; Liang, G.; Hou, E.; Luo, Y. Manure acts as a better fertilizer for increasing crop yields than synthetic fertilizer does by improving soil fertility. Soil Tillage Res. 2019, 189, 168-175. [CrossRef]

4. Zhang, X.; Fang, Q.; Zhang, T.; Ma, W.; Velthof, G.L.; Hou, Y.; Oenema, O.; Zhang, F. Benefits and trade-offs of replacing synthetic fertilizers by animal manures in crop production in China: A meta-analysis. Global Chang. Biol. 2020, 26, 888-900. [CrossRef] [PubMed]

5. Walsh, J.J.; Jones, D.L.; Edwards-Jones, G.; Williams, A.P. Replacing inorganic fertilizer with anaerobic digestate may maintain agricultural productivity at less environmental cost. J. Plant Nutr. Soil Sci. 2012, 175, 840-845. [CrossRef]

6. Borrelli, L.; Pecetti, L. Wheat yield as a measure of the residual fertility after 20 years of forage cropping systems with different manure management in Northern Italy. Ital. J. Agron. 2019, 14, 1359.

7. Chadwick, D.; Wei, J.; Yan'an, T.; Guanghui, Y.; Qirong, S.; Qing, C. Improving manure nutrient management towards sustainable agricultural intensification in China. Agric. Ecosyst. Environ. 2015, 209, 34-46. [CrossRef]

8. Rehim, A.; Khan, M.; Imran, M.; Bashir, M.A.; Ul-Allah, S.; Khan, M.N.; Hussain, M. Integrated use of farm manure and synthetic nitrogen fertilizer improves nitrogen use efficiency, yield and grain quality in wheat. Ital. J. Agron. 2020, 15, 29-34. [CrossRef]

9. Milan Ihnat, A.; Fernandes, L. Trace elemental characterization of composted poultry manure. Bioresour. Technol. 1996, 57, 143-156. [CrossRef]

10. Ronga, D.; Setti, L.; Salvarani, C.; De Leo, R.; Bedin, E.; Pulvirenti, A.; Milc, J.; Pecchioni, N.; Francia, E. Effects of solid and liquid digestate for hydroponic baby leaf lettuce (Lactuca sativa L.) cultivation. Sci. Hortic. 2019, 244, 172-181. [CrossRef]

11. Larney, F.J.; Blackshaw, R.E. Weed seed viability in composted beef cattle feedlot manure. J. Environ. Qual. 2003, 32, 1105-1113. [CrossRef] [PubMed]

12. Setti, L.; Francia, E.; Pulvirenti, A.; Gigliano, S.; Zaccardelli, M.; Pane, C.; Caradonia, F.; Bortolini, S.; Maistrello, L.; Ronga, D. Use of black soldier fly (Hermetia illucens (L.), Diptera: Stratiomyidae) larvae processing residue in peat-based growing media. Waste Manag. 2019, 95, 278-288. [CrossRef] [PubMed]

13. Bortolini, S.; Macavei, L.I.; Saadoun, J.H.; Foca, G.; Ulrici, A.; Bernini, F.; Malferrari, D.; Setti, L.; Ronga, D.; Maistrello, L. Hermetia illucens (L.) larvae as chicken manure management tool for circular economy. J. Clean. Prod. 2020, 262, 121289. [CrossRef]

14. Butler, T.A.; Sikora, L.J.; Teeinhilber, P.M.; Douglass, L.W. Compost age and sample storage effects on maturity indicators of biosolids compost. J. Environ. Qual. 2001, 30, 2141-2148. [CrossRef] [PubMed] 
15. Hussain, A.; Ahmad, M.; Mumtaz, M.Z.; Nazli, F.; Farooqi, M.A.; Khalid, I.; Iqbal, Z.; Arshad, H. Impact of integrated use of enriched compost, biochar, humic acid and Alcaligenes sp. AZ9 on maize productivity and soil biological attributes in natural field conditions. Ital. J. Agron. 2019, 14, 1413. [CrossRef]

16. Irshad, M.; Eneji, A.E.; Hussain, Z.; Ashraf, M. Chemical characterization of fresh and composted livestock manures. J. Soil Sci. Plant Nutr. 2013, 13, 115-121. [CrossRef]

17. Haase, M.; Rösch, C.; Ulrici, O. Feasibility study on the processing of surplus livestock manure into an organic fertilizer by thermal concentration-The case study of Les Plenesses in Wallonia. J. Clean. Prod. 2017, 161, 896-907. [CrossRef]

18. Brito, L.M.; Coutinho, J.; Smith, S.R. Methods to improve the composting process of the solid fraction of dairy cattle slurry. Bioresour. Technol. 2008, 99, 8955-8960. [CrossRef]

19. Olsen, J.E.; Larsen, H.E. Bacterial decimation times in anaerobic digestions of animal slurries. Biol. Wastes 1987, 21, 153-168. [CrossRef]

20. Pulvirenti, A.; Ronga, D.; Zaghi, M.; Rita, A.; Mannella, L.; Pecchioni, N. Pelletingis a successful method to eliminate the presence of Clostridium spp. from the digestate of biogas plants. Biomass Bioenergy 2015, 81, 479-482. [CrossRef]

21. Alkanok, G.; Demirel, B.; Onay, T.T. Determination of biogas generation potential as a renewable energy source from supermarket wastes. Waste Manag. 2014, 34, 134-140. [CrossRef]

22. Lehtomaki, A.; Bjornsson, L. Two-stage anaerobic digestion of energy crops: Methane production, nitrogen mineralisation and heavy metal mobilisation. Environ. Technol. 2006, 27, 209-218. [CrossRef]

23. Ronga, D.; Pellati, F.; Brighenti, V.; Laudicella, K.; Laviano, L.; Fedailaine, M.; Benvenuti, S.; Pecchioni, N.; Francia, E. Testing the influence of digestate from biogas on growth and volatile compounds of basil (Ocimum basilicum L.) and peppermint (Mentha x piperita L.) in hydroponics. J. Appl. Res. Med. Aromat. Plants 2018, 11, 18-26. [CrossRef]

24. Baffi, C.; Dell'Abate, M.T.; Nassisi, A.; Silva, S.; Benedetti, A.; Genevini, P.L.; Adani, F. Determination of biological stability in compost: A comparison of methodologies. Soil Biol. Biochem. 2007, 39, 1284-1293. [CrossRef]

25. Ronga, D.; Pane, C.; Zaccardelli, M.; Pecchioni, N. Use of spent coffee ground compost in peat-based growing media for the production of basil and tomato potting plants. Commun. Soil Sci. Plant Anal. 2016, 47, 356-368. [CrossRef]

26. Ronga, D.; Francia, E.; Allesina, G.; Pedrazzi, S.; Zaccardelli, M.; Pane, C.; Tava, A.; Bignami, C. Valorization of vineyard by-products to obtain composted digestate and biochar suitable for nursery grapevine (Vitis vinifera L.) production. Agronomy 2019, 9, 420. [CrossRef]

27. Adi, A.J.; Noor, Z.M. Waste recycling: Utilization of coffee grounds and kitchen waste in vermicomposting. Bioresour. Technol. 2009, 100, 1027-1030. [CrossRef]

28. Hachicha, R.; Rekik, O.; Hachicha, S.; Ferchichi, M.; Woodward, S.; Moncef, N.; Cegarra, J.; Mechichi, T. Co-composting of spent coffee ground with olive mill wastewater sludge and poultry manure and effect of Trametes versicolor inoculation on the compost maturity. Chemosphere 2012, 88, 677-682. [CrossRef]

29. Ronga, D.; Villecco, D.; Zaccardelli, M. Effects of compost and defatted oilseed meals as sustainable organic fertilisers on cardoon (Cynara cardunculus L.) production in the Mediterranean basin. J. Hortic. Sci. Biotechnol. 2019, 94, 664-675. [CrossRef]

30. Hara, M. Fertilizer Pellets Made from Composted Livestock Manure; Food \& Fertilizer Technology Center: Taipei, Taiwan, 2001.

31. Ncube, P.; Roberts, S.; Vilakazi, T. Regulation and rivalry in transport and supply in the fertilizer industry in Malawi, Tanzania and Zambia. In Competition in Africa-Insights from Key Industries; Roberts, S., Ed.; HSRC Press: Cape Town, South Africa, 2016; pp. 102-131.

32. Schnurer, A.; Jarvis, A. Microbiological Handbook for Biogas Plants; Swedish Waste Management U: Malmo, Sweden, 2009.

33. Bagge, E.; Sahlstrom, L.; Albihn, A. The effect of hygienic treatment on the microbial flora of biowaste at biogas plants. Water Res. 2005, 39, 4879-4886. [CrossRef]

34. Ronga, D.; Caradonia, F.; Parisi, M.; Bezzi, G.; Parisi, B.; Allesina, G.; Pedrazzi, S.; Francia, E. Using digestate and biochar as fertilizers to improve processing tomato production sustainability. Agronomy 2020, 10, 138. [CrossRef] 
35. Hagassou, D.; Francia, E.; Ronga, D.; Buti, M. Blossom end-rot in tomato (Solanum lycopersicum L.): A multi-disciplinary overview of inducing factors and control strategies. Sci. Hortic. 2019, 249, 49-58. [CrossRef]

36. Caradonia, F.; Francia, E.; Morcia, C.; Ghizzoni, R.; Moulin, L.; Terzi, V.; Ronga, D. Arbuscular mycorrhizal fungi and plant growth promoting rhizobacteria avoid processing tomato leaf damage during chilling stress. Agronomy 2019, 9, 299. [CrossRef]

37. Ronga, D.; Parisi, M.; Pentangelo, A.; Mori, M.; Di Mola, I. Effects of nitrogen management on biomass production and dry matter distribution of processing tomato cropped in southern Italy. Agronomy 2019, 9, 855. [CrossRef]

38. Eghball, B.; Wienhold, B.J.; Gilley, J.E.; Eigenberg, R.A. Mineralization of manure nutrients. J. Soil Water Conserv. 2002, 57, 470-473.

39. Cassman, K.G.; Munns, D.N. Nitrogen mineralization as affected by soil moisture, temperature, and depth. Soil Sci. Soc. Am. J. 1980, 44, 1233-1237. [CrossRef]

40. Eghball, B. Nitrogen mineralization from field-applied beef cattle feedlot manure or compost. Soil Sci. Soc. Am. J. 2000, 64, 2024-2030. [CrossRef]

(C) 2020 by the authors. Licensee MDPI, Basel, Switzerland. This article is an open access article distributed under the terms and conditions of the Creative Commons Attribution (CC BY) license (http://creativecommons.org/licenses/by/4.0/). 